\title{
WestVirginiaUniversity
}

THE RESEARCH REPOSITORY @ WVU

Graduate Theses, Dissertations, and Problem Reports

2014

\section{Technology use in the treatment and prevention of eating disorders}

Jessie T. Popelka

West Virginia University

Follow this and additional works at: https://researchrepository.wvu.edu/etd

\section{Recommended Citation}

Popelka, Jessie T., "Technology use in the treatment and prevention of eating disorders" (2014). Graduate Theses, Dissertations, and Problem Reports. 655.

https://researchrepository.wvu.edu/etd/655

This Thesis is protected by copyright and/or related rights. It has been brought to you by the The Research Repository @ WVU with permission from the rights-holder(s). You are free to use this Thesis in any way that is permitted by the copyright and related rights legislation that applies to your use. For other uses you must obtain permission from the rights-holder(s) directly, unless additional rights are indicated by a Creative Commons license in the record and/ or on the work itself. This Thesis has been accepted for inclusion in WVU Graduate Theses, Dissertations, and Problem Reports collection by an authorized administrator of The Research Repository @ WVU. For more information, please contact researchrepository@mail.wvu.edu. 


\title{
TECHNOLOGY USE IN THE TREATMENT AND PREVENTION OF EATING DISORDERS
}

\author{
Jessie T. Popelka, BS \\ Thesis submitted to the \\ Davis College of Agriculture, Natural Resources \& Design \\ at \\ West Virginia University \\ in partial fulfillment of the requirements for the degree of \\ Master of Science in Nutrition \& Food Science \\ In \\ Nutrition and Food Science \\ Thesis Committee: \\ Melissa Olfert, DrPH, MS, RDN, LD, Chair \\ Virginia Quick, PhD, RD \\ Pamela Murray MD \\ Department of Animal \& Nutritional Sciences \\ Morgantown, West Virginia \\ 2014 \\ Keywords: Eating Disorders; Technology, University \\ Copyright 2014 Jessie T. Popelka
}




\section{ABSTRACT \\ Technology Use in the Treatment and Prevention of Eating Disorders \\ Jessie T. Popelka}

Technology is changing rapidly in this global world. A radically different delivery of nutrition information and counseling is technologically feasible in fewer than five years. With about half of girls and a quarter of boys being dissatisfied with their bodies during adolescence into young adulthood, some negative consequences including development of disordered eating, eating disorders (ED) and poor psychological well-being may increase. New methods of delivery, from social media to virtual worlds will allow health care providers (HCP) to reach and interact with patients in different cities or even countries. Simple "tweets" to online videos may have a place in the near future of treatment and prevention of eating disorders.

PURPOSE: The purpose of this formative, mixed method, two-phase research study was to examine the usage, usefulness, effectiveness and convenience of technologies utilized by health care providers (HCP) in eating disorder (ED) treatment programs.

METHODS: In phase one, HCP currently working with ED patients were intensively recruited to complete an online survey on technology usage, usefulness, effectiveness, and convenience in ED treatment programs; followed by a second phase where focus groups were conducted on discussion of technology use, hindrance or asset when working with patients, how demographics effect the use of technology, whether technology aided in ED outcomes, and privacy concerns.

RESULTS: Participants $(\mathrm{N}=54)$ completing the survey represented various disciplines (e.g., 40\% Registered Dietitians (RD), 35\% school counselors, $10 \%$ physicians), and mostly 
worked in private practice (38\%) or a college setting (33\%). Technology use reported were email (62\%), text messaging (36\%), smartphone apps (34\%), CD-ROM /DVD (18\%), internetbased programs (16\%), and virtual reality (7\%). Additionally, both email and text messaging were reported as the most convenient technologies used in ED treatment programs. Focus groups $(n=9)$ discussion points were divided into similar practice environments (private practice or university).

CONCLUSION: Findings suggest that HCP use a smorgasbord of technologies in ED treatment programs and find them useful, effective, and convenient. Further there is interest on the part of the HCP to utilize technologies; however a lack of knowledge about available technologies limits use. General attitude about technology 'it can be a useful tool for integrating into ED treatment plans when it is tailored directly to the client's needs'.

LIMITATIONS: Smaller sample then anticipated in both parts of the formative research with a small representation of the different health care practitioners including dietitians. 


\section{ACKNOWLEDGEMENTS}

I would like to thank my committee members Dr. Melissa Olfert, Dr. Virginia Quick, and Dr. Pamela Murray for providing me with the guidance and encouragement to complete this project throughout the past two years.

I would also like to thank others who have contributed to the project including Dr.

Christa Ice for her expertise in statistical analysis as well other graduate students who assisted with information gathering.

Additionally, this project would not be possible without the healthcare providers that participated in the study by taking the survey and contributed in discussion in the focus groups. 


\section{TABLE OF CONTENTS}

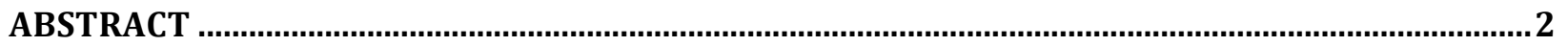

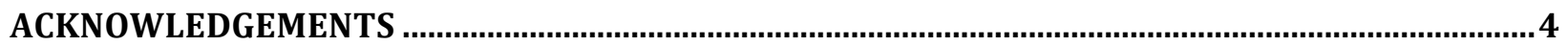

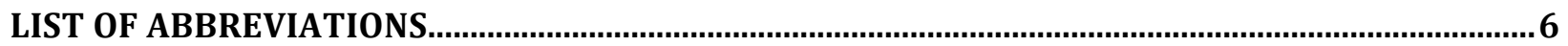

LIST OF TABLES

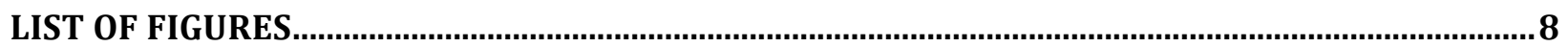

CHAPTER 1

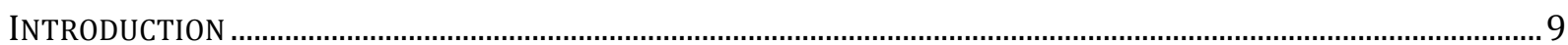

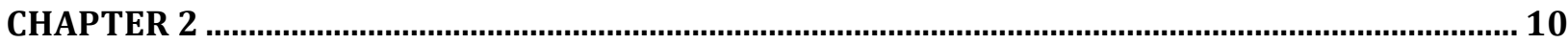

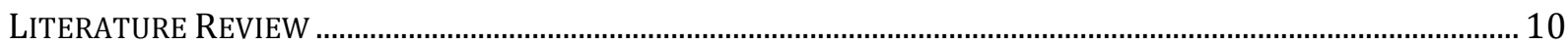

THEORETICAL FOUNDATION FOR NOVEL TECHNOLOGY APPROACHES IN DISEASE ................. 11

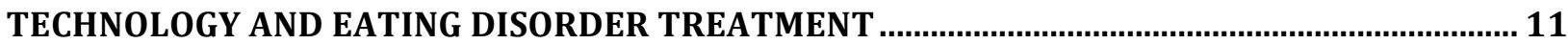

TECHNOLOGY USE ACROSS PREVENTION \& TREATMENT SPECTRUM ......................................... 14

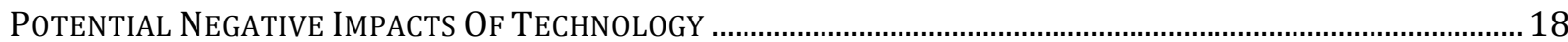

POTENTIAL APPLICATIONS OF THESE PROGRAMS IN A HIGHER EDUCATION SETTING .......... 20

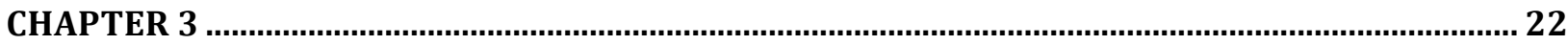

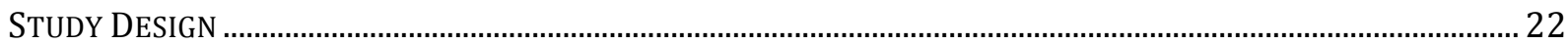

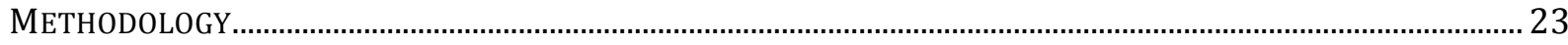

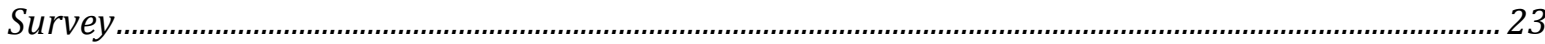

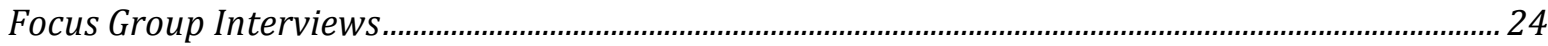

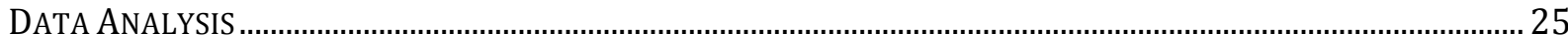

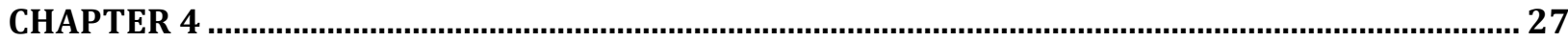

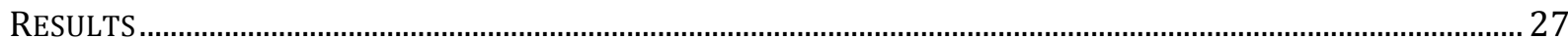

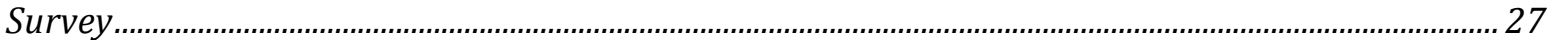

The mean survey completion time was 2 minutes 14 seconds. ............................................................ 27

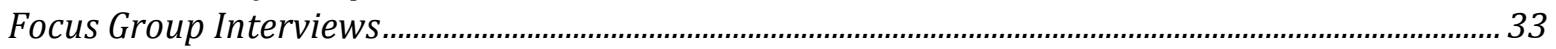

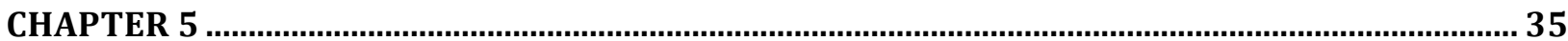

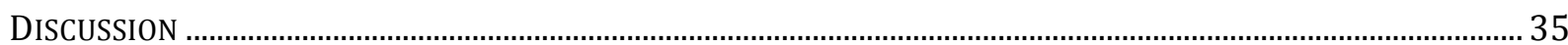

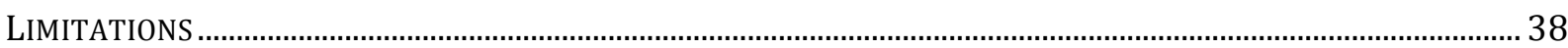

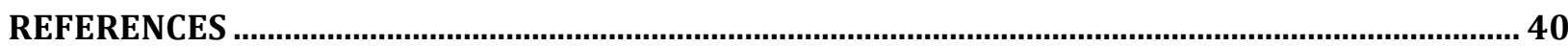

48. MCDONALD, J.H. 2009. HANDBOOK OF BIOLOGICAL STATISTICS (2ND ED.). SPARKY HOUSE PUBLISHING, BALTIMORE, MARYLAND. 49. PROGRAM: ELECTRONIC LIBRARY \& INFORMATION SYSTEMS. 2013, VOL. 47 ISSUE 4, P424-436. 13P. ............................................... 44

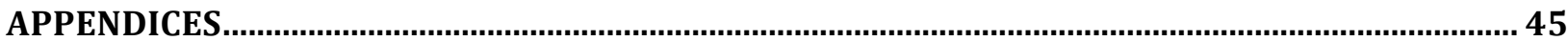

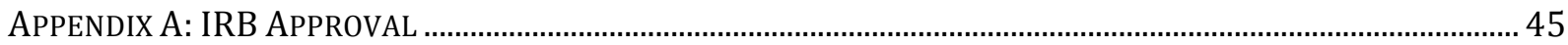

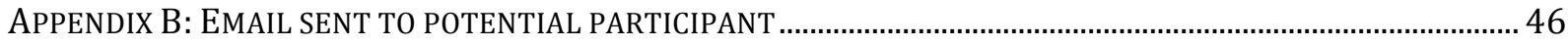

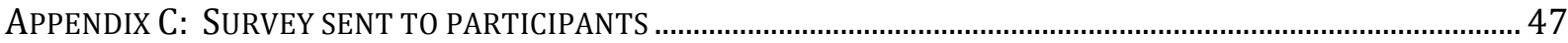

APPENDIX D: FOCUS GROUP QUESTIONS AND PROMPTS................................................................................. 51 


\section{LIST OF ABBREVIATIONS}

HCP - Health Care Professional

AN - Anorexia Nervosa

BN - Bulimia Nervosa

VR - Virtual Reality

EDNOS - Eating Disorder Not Otherwise Specified

NCAA - National Colligate Athletic Association

RD - Registered Dietitian 


\section{LIST OF TABLES}

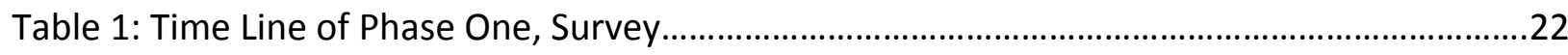

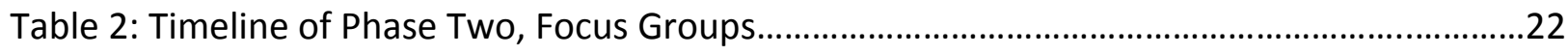

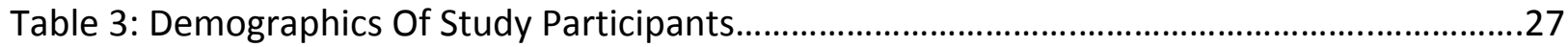

Table 4: Percent's And Frequencies Of Current Technologies Used By Health Care Professionals $(\mathrm{N}=54)$ In Eating Disorder Treatment/Intervention.....................................................................28

Table 5. Health Care Professionals Reported Satisfaction Of The Usefulness, Effectiveness, And Convenience For Health Care Professionals And Patients In Using Technology For Eating

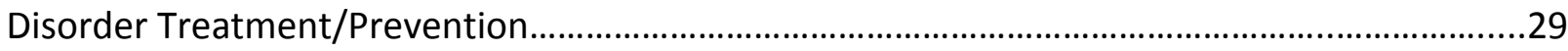

Table 6. Chi Square Test of Number of Technologies Used and Practice Environment..............32 


\section{LIST OF FIGURES}

Figure 1. Technologies That Health Care Professionals Feel Would Be Useful To Integrate Into Eating Disorder Treatment/Interventions.................................................................................. 30

Figure 2. Technologies That Health Care Professionals Plan To Implement Into Their Future

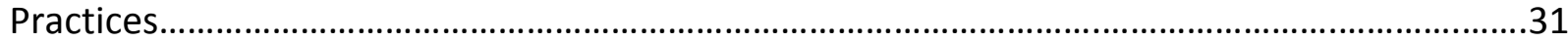




\section{Chapter 1}

\section{Introduction}

As technologies evolve, it is advantageous for health care professionals (HCP) to examine whether utilization of new innovative tools can be incorporated in their practice. The use of technology-based treatments is currently being investigated as a supplementation to traditional therapy, or as a replacement for treatment in those suffering from eating disorders. ${ }^{1}$ Since university and/or college campuses tend to be well equipped and updated with the latest electronic devices needed to utilize these potential new treatments, computer, phone, or virtual reality based treatments may be more feasible to test as a beneficial tool. The purpose of this study is to identify what technologies are being incorporated into ED treatments in University settings as well as elsewhere, to get a sense of the HCP attitudes toward their effectiveness and usefulness, and to identify correlations between demographics of a facility and their technology use. 


\section{Chapter 2}

\section{Literature Review}

The purpose of this literature review is to describe current technologies being examined in ED intervention, their possible role in the university setting, and the need for future research in this area.

A 2013 study from Educause surveyed approximately 28,000 college students and found that $86.1 \%$ of students owned a cell phone with an additional $77 \%$ reporting they owned a smartphone with Internet access ${ }^{49}$ Additionally, around $85 \%$ of college students reported having text messaging services. Overall, nearly all students (98\%) owned a computer. Almost all students (99.9\%) regularly used email and had access to high-speed Internet (91.5\%). ${ }^{3}$ Thus, the potential to reach college students through electronic devices such as the computer or phone is vast.

The use of technology is not the only area with high prevalence rates among college students. Body dissatisfaction and disordered eating behaviors, common risk factors for eating disorders, ${ }^{4}$ are also highly prevalent among college students. ${ }^{5}$ College students are thought to be at greater ED risk given the life stressors of transitioning from high school to college. ${ }^{7}$ For instance, $13.5 \%$ of college females screened positively for ED symptoms, ${ }^{8}$ compared to $1.3 \%$ of the general population. ${ }^{6}$ The incidence of ED may be underreported, as symptoms may exist for a substantial length of time before they are detected due to the secretive nature of the disease. $^{9}$

Given that body dissatisfaction and disordered eating behaviors are highly prevalent among college students, ${ }^{5}$ which may place them at ED risk, colleges or universities may be the 
ideal place to implement some of the new technologies being investigated today such as text, email, or even virtual reality. ${ }^{10-12}$ These programs may be useful across the entire ED treatment spectrum, from screening, to prevention, intervention and even maintenance.

Advanced technologies are becoming even more part of everyday life than ever before. Although some technologies are relatively new, researchers are looking at the use of these technologies in the treatment of mental diseases such as ED. ${ }^{14}$

\section{Theoretical Foundation For Novel Technology Approaches In Disease}

Diffusion of Innovations seeks to explain how innovations are taken up in specific populations. ${ }^{47}$ This innovation may be an idea, a behavior, or object. There is valuable insight to understanding the process of social change by seeking what qualities make an innovation spread quickly, the importance of peer-peer conversations or peer-expert conversations and networks for both, understanding the needs of different user segments. In this theoretical framework, in all new technologies there are early adaptors, early majority, late majority and laggards. Due to the novelty of this research study the focus is in the early adaptors.

\section{Technology and Eating Disorder Treatment}

Mobile phones, including smart phones with internet and application capabilities, are one of the most widespread technologies, and have the potential to 1) provide better access to eating disorder treatment, 2) provide interactive feedback, 3) guarantee availability of information any time anywhere, and 4) improve treatment compliance and acceptance rates. ${ }^{15}$

The use of text messaging in the treatment of Bulimia Nervosa (BN) has been received well by young adults. For instance, during a 12-week cognitive behavioral therapy treatment patients submitted a text message each night to their health care providers that reported their 
ED behaviors for the day such as binge and purge episodes and the urgency they felt towards these behaviors. This study looked at patient's acceptability to this style of treatment and not at specific outcomes. Patients found the intervention to be convenient, adaptable, and well tolerated overall. ${ }^{12}$ Texting provides a similar therapeutic tool to the more traditional paper diary that is more discrete, quicker, and provides a record of certain behaviors including time of day and date. ${ }^{12}$

In contrast to the Shapiro et al study, Robinson et al found limited acceptance and high attrition rates of a six month long aftercare intervention of those with $\mathrm{BN}$ that utilized text messaging as part of the treatment. ${ }^{16}$ More than half of patients $(57 \%)$ dropped out of the study. A follow-up questionnaire revealed that $86 \%$ of patients claimed they would "definitely not" or "probably not" participate again and 77\% felt they would have coped just as well without the program. These patients felt that very little effort was required to participate in the program since they had limited contact with health care providers (i.e., only one month feedback), which may have accounted for the differing outcomes compared to the Shapiro et al study.

A recent study among outpatients with either BN or EDNOS (eating disorder not otherwise specified) patients using a tailored text message approach over a 16-week period showed significantly better health outcomes then a control group. This study suggests that the use of tailored text message responses from health care providers may be the difference between success and failure in the use of text messaging in ED intervention. ${ }^{14}$ Texting in conjunction with a public service announcement ads showed improved body satisfaction outcomes in women suffering from low body satisfaction. ${ }^{17}$ 
The use of email is being examined as a supplement to face-to-face counselor-patient interactions. ${ }^{1}$ Patients who received the email therapy in conjunction with a more intricate treatment plan reported greater contact with clinicians and placed greater emphasis on therapeutic tasks. ${ }^{18}$ Thus, providing even brief feedback between office visits can provide a patient with comfort knowing the clinician is present, listening, and thinking about them. ${ }^{18}$ Email may also provide a format for discussing some of the more mundane topics such as calorie counts and symptom logs that can free up office hours for more crucial treatment conversations. $^{19}$

Virtual reality (VR) has considerable potential for assessment and treatment of mental health issues such as eating disorders. ${ }^{10}$ During a VR experience a head mounted display system is worn and a realistic visual environment, such as exposure to anxiety producing foods or situations, is created for the recipient to explore. ${ }^{1}$ VR can be a way to explore issues without provoking threatened or anxious feelings that may cause a patient to refuse treatment. ${ }^{20}$ VR also allows a patient to relive a representation of a past experience, and subsequently, explore that patient's perception of the event and possibly reinterpret and change these perceptions. ${ }^{10}$

Furthermore, VR can be useful in enhancing a clinician's control over treatment, whereas in real-life situations it can be difficult to control all possible variables. ${ }^{20}$ It may also increase patient motivation by allowing patients to observe changes in their virtual selves. ${ }^{1}$ Although VR has been shown useful in many psychological disorders, few have looked at ED specifically. ${ }^{10}$ Some studies have shown a positive effect of VR on lowering anxiety levels and improving body image perception in those with ED. ${ }^{10,20}$ 
Smart phone apps are another technology being incorporated into ED treatments programs. The apps used tend to be general diet or fitness tracking tools, and are not tailored to ED specifically. To our knowledge there currently is no scientific research looking at the efficacy or effectiveness of these programs, however with some of the apps having up to 27,000 users, this area has the potential to reach a large audience (itunes.com ${ }^{\circledR}$ ). Apps have the potential to be a cost efficient and convenient way to monitor symptoms or conduct widespread ED screenings.

There are a variety of self-help programs currently available on the Internet that focus on psychological problems such as phobias, obesity, sexual dysfunctions and tobacco addiction. ${ }^{15}$ Programs that are entirely self-directed have been shown to produce positive results in those with binge eating disorders and $\mathrm{BN} .^{21,22}$

Regardless of the technology-based treatment used, they will "only ever be as good as the human effort that went into making them, and it is precisely this human effort that our patients relate to."19, p. 152

\section{Technology use across prevention \& treatment spectrum}

One of the most intriguing possibilities of technology is its application across the entire spectrum of the disease. From screening for ED risk factors and early detection, to maintenance and relapse prevention, lending to a wide variety of potential uses.

Early intervention is key to eating disorder prevention and recovery. ${ }^{23}$ Screening programs for ED can be found in a wide variety of places from general health websites to women's issue magazines. The validity and reliability of eating disorder screening tools heavily depend on whom they are targeted towards (e.g., child vs. adult) and whether they are clear in 
purpose. ${ }^{24}$ Therefore, similar to other areas of the ED intervention spectrum, one screening tool may not be sufficient to capture all incidences of ED. Specifically tailored eating disorder screening tools are better. It can be difficult to evaluate the seriousness of eating disorder risk factors as the majority of young girls are frequent dieters, but over time seemingly innocent dieting, exercise, and weight control behaviors can lead to full blown ED by young adulthood. ${ }^{23}$ Technology could provide a platform for dissemination of ED screening tools that could assist individuals in finding help early on.

Relapse is common following ED treatment, and ongoing support is usually necessary to continue improvement, prevent relapse, consolidate the gains achieved during treatment, and achieve a successful transition post treatment to day-to-day life. ${ }^{25}$ Many patients find frequent communication during this phase helpful, however it may be difficult to communicate directly with a therapist when transitioning from intensive treatment programs into maintenance programs. Several studies have shown benefits with technology based maintenance programs in their ability to be more helpful than traditional relapse prevention programs. ${ }^{14,25}$

$E D$, particularly those that go untreated for extended periods of time, can result in a variety of health problems including joint pain, gastrointestinal problems, fatigue, and even death. ${ }^{26}$ Despite the improvement in quality and effectiveness of mental health treatment, many people choose not to seek treatment, or lack adherence to the program. ${ }^{27}$ There are many barriers to ED treatment, and these may be influenced by demographics such as race/ethnicity. ${ }^{28}$ For instance, a study that targeted minority groups indicated that $43 \%$ of individuals who felt they had an ED never sought treatment. Of those who sought treatment, only $5 \%$ received it. ${ }^{29}$ Some common reasons for not seeking treatment may include financial 
difficulties, lack of health insurance, fear of being labeled, not knowing about available resources, and feelings of shame and discrimination. ${ }^{29,30}$

Cost can be a huge barrier in any medical situation, and eating disorders are no different. While cost can be a barrier in seeking and receiving treatment of any mental illness, care needs to be taken to ensure that utilizing more cost efficient treatments are not simultaneously lowering the effectiveness. Particularly in the case of ED, which are among the most obstinate and potentially life threatening of all psychiatric disorders. ${ }^{31}$ One study that looked at the cost effectiveness of self-help treatment for use in the intervention of recurrent binge eating found that patients using this treatment were less likely to binge at a 6 and 12 month follow up when compared to a control group receiving more traditional face-to-face therapy. The study also noted that the self-help intervention was about half the cost of the traditional therapy. ${ }^{32}$ This study shows that self-help style interventions have the potential to be just as effective, if not more effective as traditional therapies; however, more research is needed to determine whether this trend is seen across differing technology-based interventions.

Because ED has a reputation for being expensive to treat, third-party payers are now showing a tendency to limit the care provided for this illness, especially in the United States. With the typical cost of treatment being estimated at $\$ 30,180$ and the adequate care treatment at $\$ 119,200$ per individual, the cost factor alone can put treatment out of reach for many sufferers with ED particularly those whose insurance does not exist. ${ }^{33}$

Both geography and availability can also be seen as barriers to seeking and receiving ED treatment. One study in Australia received an overwhelming response rate after advertising a 
self-help program for bulimia in a popular women's magazine. Many of the respondents indicated that there was a lack of treatment available where they resided. ${ }^{21}$ Specialized treatment centers are not available in all cities and in some cases may be hundreds of miles away.

A specific advantage of technology-enhanced mental health care treatments is reaching previously underserved populations. ${ }^{14}$ One study showed that promoting the availability of treatment electronically helped engage individuals who otherwise would have been unlikely to request help. ${ }^{11}$ The ability to get help without having to travel was cited as one of the most helpful components to an online ED treatment program, along with the ability to get expert advice post treatment and the ability to ask questions whenever needed. ${ }^{25}$

A common reported barrier to treatment is the shame and stigma that comes from seeking help. ${ }^{30}$ Although few published studies have examined the stigmatization of ED specifically, mental health disorders overall are prone to generalization and discrimination. ${ }^{34,35}$ Stewart et al suggested that ED might be more stigmatized than any other mental health disorder. ${ }^{34}$ After surveying a random sampling of people it was found that participants felt that anorexia patients could "pull themselves together if they wanted to" and were "to blame for their own condition" and "acting this way for attention" more so than traditional mental health disorders such as schizophrenia. ${ }^{34}$ When participants were surveyed about their beliefs of ED risk factors, these young adults believed that self-discipline, lack of social support, and parenting contributed more to ED development, while biological factors contributed less. ${ }^{34}$ A huge benefit of technology-based treatments such as Internet based programs is the convenience and ease of contact. Individuals can seek help or information in a discrete manner 
without fear of prejudice. ${ }^{22}$ Some ethnic minorities may feel as though their disorders are dismissed due to a stigma that eating disorders do not exist in their subcultures, ${ }^{28}$ and are therefore even less likely than others to seek treatment. ${ }^{30}$ The anonymity and privacy that technology based ED treatments can provide to such a traditionally secretive disease can have vast implications on encouraging those with suspected ED to seek treatment despite stigmatism and shame.

A belief that one should be able to deal with a health issue on your own is another common barrier to seeking treatment and in fact is reported by up to $73 \%$ of those not seeking treatment for a suspected mental health concern. ${ }^{36}$ The use of self-help online programs may encourage an ED patient because they feel they have more control over their own treatment. ${ }^{22}$

Minorities may have cognitive and behavioral issues more closely related to their ethnic backgrounds, and a traditional approach not addressing these issues can discourage these populations from seeking or continuing treatment. ${ }^{28}$ This is just one example of how being able to tailor treatment specifically to the individual can have beneficial effects. Patients respond to various types of treatment differently and some of the online programs have an advantage in offering a multi-communication platform that allows the individual to choose what type of interaction they prefer such as individual chat, group chat, telephone hotlines or professional monitoring and feedback. ${ }^{25}$

\section{Potential Negative Impacts Of Technology}

Although technology may provide a unique and diverse platform for ED prevention and screening, there are several things that need to be considered. 
While there have been some concerns that the therapist client relationship may not be imitated via web-based interaction, when frequent and regular messages are exchanged and a substantial amount is written, signs of a therapeutic relationship emerge. ${ }^{11}$ Although some may view these types of treatment as cold or mechanical, due to the nature of eating disorders whereby patients tend to suffer from low self-esteem and are secretive about their disorder, ${ }^{37}$ this type of interaction could be preferred by some patients. One study that used text messaging as a treatment for BN cited that multiple participants claimed the treatment was "too formal", "computerized", and "impersonal" suggesting that this treatment style may not be appropriate for everyone. ${ }^{16}$

Individuals with ED are a highly sensitive population. In technology therapies that are email based, the patient is left without any verbal cues or voice tones to aid interpretation. This has the potential for misunderstandings and distorted interpretations of meaning, particularly among sensitive individuals. ${ }^{18}$ Another concern is the ability for programs to detect and address serious disorder symptoms that might otherwise be screened during a more traditional in person intervention style. ${ }^{38}$ The plausibility of dealing with delicate issues usually addressed in therapy such as sexual abuse also needs to be considered. ${ }^{38}$

It is not uncommon for delicate issues such as sexual abuse to go hand in hand with eating disorders. ${ }^{39}$ The exploration of such private topics is a limiting factor when considering treatment styles. ${ }^{38}$ While some patients may prefer to discuss these types of issues in a face-toface manor, others may feel more comfortable opening up in a text or email style format. ${ }^{1,18,19}$ Either way, crisis management needs to be considered and built into such programs. ${ }^{40}$ 
Technology always comes with its share of hurdles, and utilizing it in mental health practices is no exception. Computer literacy by both the therapist and the patient could potentially be an impediment to these types of treatments. While most adolescent patients will have grown up with computers today, the same cannot be said for therapists. ${ }^{19}$

Privacy and confidentiality issues are a concern whenever technology is involved.

Breaches in confidentiality can have severe consequences in ED patients including symptom deterioration and crisis. ${ }^{1}$ Unintentional sharing of information can be a problem, especially if patients share a computer, email address or phone number with others. Clinicians being mindful to reply in a discrete manner, and not including the patient's original messages in their response could minimize this issue. Patients should be made aware of the potential for confidentiality issues up front. ${ }^{18}$ Patients may also feel uncomfortable using Internet or CDROMs style treatments in public if they contain audio segments or vibrantly colored visuals. ${ }^{38}$

Due to some of the possible problems with eating disorder interventions delivered via computer or phone, it has been suggested that this treatment style be promoted for enhancement of face-to-face interaction, as opposed to replacement to defend against the potential for amplified isolation. ${ }^{40}$

\section{Potential applications of these programs in a higher education setting}

A review of the current literature has shown some of the current technologies that have potential in ED interventions and their treatment implications. Currently lacking is the potential for these treatments in higher education settings. Nationwide budget cuts at public universities force schools to look at where they can to reduce spending without compromising the quality of the college experience for their students. ${ }^{41}$ Universities encourage diversity on campuses as 
much as possible, which may require variability in types of help available. ${ }^{42}$ Many of the aforementioned barriers to treatment are seen regularly on college campuses, perhaps making it an ideal location to implement some of these new programs.

Because access to care and screening can be an issue for the general population, some universities have the unique opportunity to provide broad prevention campaigns and provide access to treatment to the target eating disorder demographic. There is also the ability to incorporate body image workshops and other prevention strategies into coursework furthering the scope of potential help. ${ }^{44}$

Intervention and prevention programs have been available in universities since the mid1980 's, yet little success has been shown. ${ }^{44}$ In most studies of ED a large number of individuals fail to engage in treatment or drop out. Increasing acceptance, usability, and completion should be a priority in ED intervention. ${ }^{12}$ One study found an average dropout rate of $31 \%$ from Internet-based treatment of psychological disorders, however they could not pinpoint any specific variables that made individuals more likely to drop out. ${ }^{45}$ Improving attrition rates could be a step in the right direction to improving treatment programs overall, removing some of the barriers to treatment with technology-enhanced methods may help.

Due to the increase in technology driven therapy practices being used in ED treatment today as well as their vast potential in higher education settings, further research is needed to determine whether college campuses are implementing such practices into their student health programs. Future research is also needed to determine how universities view technology-based eating disorder programs and their willingness to implement them on their college campuses. 


\section{Chapter 3}

\section{Study Design}

This formative research study has two phases: phase one is a 24 question survey targeting health care professions (HCP) including dietitians to determine the current scope of awareness and use of various technologies in ED; the second phase is a focus group approach to further investigate specific HCP that work in the University setting and outside of it to determine comfort and positive and negative impacts of using this technology. The objectives of this study were to 1 . To identify whether eating disorder treatment facilities associated with Universities, as well as elsewhere, are implementing technologies into their eating disorder care programs, 2. Whether those who are using such programs are finding them to be useful, effective, or convenient and 3. To identify any correlations between demographics and increased technology use.

Table 1: Timeline Of Phase 1, Survey

\begin{tabular}{|c|c|c|c|c|c|c|c|c|c|c|c|}
\hline $\begin{array}{l}\text { Survey } \\
\text { Developm }\end{array}$ & & & & & & & & & & & \\
\hline $\begin{array}{l}\text { Feedback } \\
\text { from HCP } \\
(n=3)\end{array}$ & & & & & & & & & & & \\
\hline Recruitme & & & & & & & & & & & \\
\hline $\begin{array}{l}\text { Survey } \\
\text { distributio }\end{array}$ & & & & & & & & & & & \\
\hline Analysis & & & & & & & & & & & \\
\hline & $\begin{array}{l}\text { October } \\
2012\end{array}$ & $\begin{array}{l}\text { November } \\
2013\end{array}$ & $\begin{array}{l}\text { December } \\
2012\end{array}$ & $\begin{array}{l}\text { January } \\
2013\end{array}$ & $\begin{array}{l}\text { February } \\
2013\end{array}$ & $\begin{array}{l}\text { March } \\
2013\end{array}$ & $\begin{array}{l}\text { April } \\
2013\end{array}$ & $\begin{array}{l}\text { May } \\
2013\end{array}$ & $\begin{array}{l}\text { June } \\
2013\end{array}$ & July 2013 & $\begin{array}{l}\text { August } \\
2013\end{array}$ \\
\hline
\end{tabular}

Table 2: Timeline of Phase 2, focus groups

\begin{tabular}{|l|l|l|l|l|l|}
\hline $\begin{array}{l}\text { Focus group } \\
\text { developed }\end{array}$ & & & & & \\
\hline $\begin{array}{l}\text { Feedback from HCP } \\
(\mathrm{n}=3)\end{array}$ & & & & & \\
\hline Recruitment & & & & & \\
\hline Focus groups held & & & & & \\
\hline Analysis & & & & & \\
\hline & & & & \\
\hline
\end{tabular}




\section{Methodology}

\section{Survey}

\section{Recruitment of Participants}

Approximately 7,830 health care professionals around the world from electronic listservs (i.e., Sports Cardiovascular And Wellness Nutrition Dietetics Practice Group (SCAN), The Academy of Eating Disorders Association, and Prevention Research group) were invited to anonymously participate in a web-based survey if they had direct contact and participation in the treatment of patients with eating disorders in any professional setting (Appendix B). Additional phone calls were made to 94 Universities in trying to locate contact information for health care professionals that directly work with student eating disorder issues. Around onethird of these phone calls resulted in retrieval of direct contact information (i.e., email address) of health care professionals to send the web-based survey too. Recruitment emails and phone calls were also made to 46 identified eating disorder treatment programs in all areas of the United States (US).

\section{Materials}

Participants were invited to anonymously complete a 24-item survey concerning the use of technology in the treatment and prevention of eating disorders (Appendix C). Several professionals $(\mathrm{N}=34)$ reviewed a draft of the survey for content validity and revisions were made based on their feedback. This study received approval from the Institutional Review Board (IRB) at West Virginia University.

Demographic questions (7 items) with multiple-choice answer selections were used to identify survey participants' working environment such as their practice environment, state of 
facility, population density, and their role in ED intervention. If participants were associated with a University they were also asked about their current student enrollment size, National Colligate Athletic Association (NCAA) participation, and student health insurance availability. Seven survey questions with multiple-choice responses (yes/no/not sure) were used to determine technologies currently being used (text messaging, Email, smart phone apps, virtual reality, CD-ROMs or DVD's, internet based programs). Responses were assigned numbers for analysis purposes such as $0=$ No, 1=yes, $2=$ Not Sure, etc. For each technology reported as being used by the participant, a follow-up survey question with a 5-point Likert scale (1=very dissatisfied to 5=very satisfied) examined self-reported usefulness, effectiveness, and convenience for both HCP and ED patients.

\section{Focus Group Interviews}

Formative interviews using a qualitative approach was used to study the experiences and opinions of HCP towards the use of technology in the treatment of ED. Data was collected through three focus groups ${ }^{46}$, as a way to stimulate discussion on the various aspects of technology in treating ED.

Participants were invited from the pool of individuals who had been contacted to complete the survey portion of the study, as well as other health care professionals who work directly with eating disorder patients, and were recruited through telephone contact and email. Sampling was purposive seeking participation from a variety of treatment facilities and health care professionals. The sample included Registered Dietitians (RD's) who worked in both university and private practice settings. An attempt was made to group participants into like practice environments, either University or private practice, to encourage discussion and 
comparison between similar types of facilities. Each group took place on a conference call and was facilitated by the authors. Proceedings were transcribed from audio recordings and two note takers were present to capture responses.

\section{Data Analysis}

As for the survey, means, percent's, and frequencies for all demographic and remaining survey questions were conducted. Sample size appropriateness ( $n>10$ per predictor) using correct model specification was checked using Spearman's correlation.$^{48}$ Spearman's correlation coefficients were also conducted to determine correlations between number of technologies used and the various demographic questions. P-values below .05 were considered statistically significant. Chi square test was also conducted to further assess significant associations that were identified between demographics. All analyses were conducted in SAS

\section{3.}

Qualitative content analysis of the focus group interviews with HCP were conducted by two researchers using standard procedures as stated by Krueger and Casey (2009). ${ }^{46}$ Expanded summaries of interview respondents' answers to each question were written using a word processor. Each question listed all of the interview respondents' answers and was marked with identification letters to help facilitate coding and analysis. Creation of a code list is an inductive task that is based on interview responses. This involved reading responses from the interviews and then compiling a codebook containing a list of mnemonic codes along with their definitions. As each new idea or belief was encountered, it was added to the codebook. Saturation of content is determined by theoretical saturation "the rule of thumb has been to conduct three or four focus groups with a particular audience and then decide if additional 
groups should be added to the study." ${ }^{46}$ Further, "the ideal size of a focus group for most noncommercial topics is five to eight participants". All HCP demographic information was analyzed to generate descriptive statistics. 


\section{Chapter 4}

\section{Results}

\section{Survey}

The mean survey completion time was 2 minutes 14 seconds.

\section{Participants}

Participants represented various disciplines with $40 \%$ RD, 35\% counselors, $10 \%$ physicians, $4 \%$ researchers, and $10 \%$ listed as other. (Table 3 )

Table 3. Demographics of study participants $(\mathrm{N}=54)$

\begin{tabular}{|c|c|c|}
\hline & $\mathrm{N}$ & $\%$ \\
\hline \multicolumn{3}{|c|}{ Student enrollment } \\
\hline$<5,000$ & 2 & 9.1 \\
\hline $5,000-10,000$ & 2 & 9.1 \\
\hline $10,000-20,000$ & 2 & 9.1 \\
\hline $20,000-30,000$ & 6 & 27.3 \\
\hline $30,000-40,000$ & 1 & 4.6 \\
\hline$>40,000$ & 9 & 40.9 \\
\hline \multicolumn{3}{|l|}{ Location } \\
\hline Urban & 31 & 63.3 \\
\hline Suburban & 15 & 30.6 \\
\hline Rural & 3 & 6.1 \\
\hline \multicolumn{3}{|l|}{ Member of NCAA } \\
\hline Yes & 19 & 41.3 \\
\hline No & 4 & 8.7 \\
\hline No Association & 23 & 50.0 \\
\hline \multicolumn{3}{|c|}{ Student Health Insurance } \\
\hline Yes & 22 & 48.9 \\
\hline No Association & 23 & 51.1 \\
\hline \multicolumn{3}{|l|}{ Region } \\
\hline South & 12 & 25.0 \\
\hline Midwest & 13 & 27.1 \\
\hline Northeast & 9 & 18.8 \\
\hline West & 7 & 14.6 \\
\hline Outside US & 7 & 14.6 \\
\hline \multicolumn{3}{|c|}{ Number of Technologies used } \\
\hline None & 12 & 23.5 \\
\hline One & 12 & 23.5 \\
\hline Two & 12 & 23.53 \\
\hline Three & 10 & 19.6 \\
\hline Four & 4 & 7.8 \\
\hline Five & 1 & 2.0 \\
\hline
\end{tabular}


Participants practiced in various working environments with $38 \%$ in a private practice setting, 33\% working in a University or College setting, $21 \%$ at an eating disorder treatment center, and $8 \%$ listed as other (Other responses included military, tertiary care pediatric hospital, and university hospital). Participant locations varied across the US with 4 responses outside the US including South Korea, United Kingdom, New Zealand, and Canada. Most participants reported working in an urban setting (63\%) with some in a suburban (31\%), and rural setting (6\%).

For participants that primarily work in University setting, 46\% reported having a student enrollment of 30,000 students or more. Additionally, over one-third (41\%) reported their program was associated with the NCAA, and all of them reported their University offered some type of student health insurance.

Technology in Eating Disorder usage, usefulness, effectiveness, and convenience

The majority of participants reported using one or more technology as part of their eating disorder intervention and treatment (Table 4).

Table 4: Percent's and frequencies of current technologies used by health care professionals $(\mathrm{N}=52)$ in eating disorder treatment/intervention

\begin{tabular}{lcc}
\hline Type of technology & $\begin{array}{c}\text { Yes } \\
\text { N (\%) }\end{array}$ & $\begin{array}{c}\text { Not Sure } \\
\mathbf{N}(\%)\end{array}$ \\
\hline Text messaging & $18(36)$ & $3(6)$ \\
Email & $31(62)$ & $2(4)$ \\
Smart Phone apps & $15(34)$ & $3(7)$ \\
Virtual Reality & $3(7)$ & $5(11)$ \\
CD-ROM or DVD & $8(18)$ & $4(9)$ \\
Internet based & $7(16)$ & $3(7)$ \\
program & $6(14)$ & $9(20)$ \\
\hline Other*
\end{tabular}

* Other technologies used include Skype, EMR 
Email was the most commonly reported technology used (62\%), followed by text messaging (36\%), smartphone apps (34\%), CD-ROM or DVD (18\%), Internet based programs (16\%), and virtual reality (7\%). Few participants (6\%) reported using technologies other than those listed, including biofeedback programs, electronic medical records, Skype, TED talks, computerized testing, and iPod meal support messages.

Using Email for eating disorder treatment/interventions was reported as the most useful (4.06 \pm 1.00$)$ (Table 5).

Table 5. Health care professionals reported satisfaction of the usefulness, effectiveness, and convenience for health care professionals and patients in using technology for eating disorder treatment/prevention*

\begin{tabular}{lccccccccc}
\hline $\begin{array}{l}\text { Type of } \\
\text { technology }\end{array}$ & & \multicolumn{3}{c}{ Usefulness } & \multicolumn{2}{c}{ Effectiveness } & \multicolumn{2}{c}{$\begin{array}{l}\text { Convenience for } \\
\text { health professional }\end{array}$} & $\begin{array}{c}\text { Convenience for } \\
\text { patient }\end{array}$ \\
\hline & $\mathbf{N}$ & Mean & SD & Mean & SD & Mean & SD & Mean & SD \\
Email & 35 & 4.06 & 1.00 & 3.86 & 1.06 & 4.21 & 1.12 & 4.26 & 1.04 \\
Text & 23 & 3.87 & 1.10 & 3.70 & 1.06 & 3.65 & 1.34 & 4.26 & 1.18 \\
$\begin{array}{l}\text { Smart phone } \\
\text { apps }\end{array}$ & 22 & 3.68 & 1.09 & 3.64 & 1.05 & 3.76 & 1.09 & 3.64 & 1.18 \\
$\begin{array}{l}\text { Virtual Reality } \\
\text { CD-ROM or }\end{array}$ & 7 & 2.86 & 1.35 & 2.86 & 1.35 & 2.71 & 1.25 & 2.86 & 1.35 \\
DVD & 10 & 3.80 & 1.55 & 3.80 & 1.55 & 3.80 & 1.55 & 3.70 & 1.57 \\
$\begin{array}{l}\text { Internet based } \\
\text { program }\end{array}$ & 9 & 3.67 & 1.58 & 3.50 & 1.69 & 3.63 & 1.77 & 3.67 & 1.66 \\
\begin{tabular}{l} 
Other \\
\hline
\end{tabular} & 8 & 3.63 & 1.69 & 3.38 & 1.60 & 3.63 & 1.69 & 3.63 & 1.77 \\
\hline
\end{tabular}

*Score range from 1 (very dissatisfied) to 5 (very satisfied)

Text, smart phone apps, virtual reality, CD-ROMs or DVD, Internet based programs, and other forms of technology received lower satisfaction mean scores. Email also had the highest satisfaction mean scores for effectiveness in eating disorder 
treatment/interventions (3.86 \pm 1.06$)$, while text, smart phone apps, virtual reality, CDROMs or DVD, internet based programs, and other forms of technology received lower satisfaction mean scores. Email was also at the top in satisfaction ratings in convenience for HCP (4.21 \pm 1.12$)$. Email and text both had the highest satisfaction mean scores for convenience in using ED treatment/intervention technologies for patients (Email:

4.26 \pm 1.04 , Text: $4.26 \pm 1.18)$.

When asked about technologies participants felt would be useful to integrate into ED treatment, $80 \%$ reported Internet based programs, 53\% smart phone apps, 33\% email and virtual reality, 27\% text and CD-ROM, and 7\% other (i.e., Skype) (Figure 1).

Figure 1. Technologies that health care professionals feel would be useful to integrate into eating disorder treatment/interventions

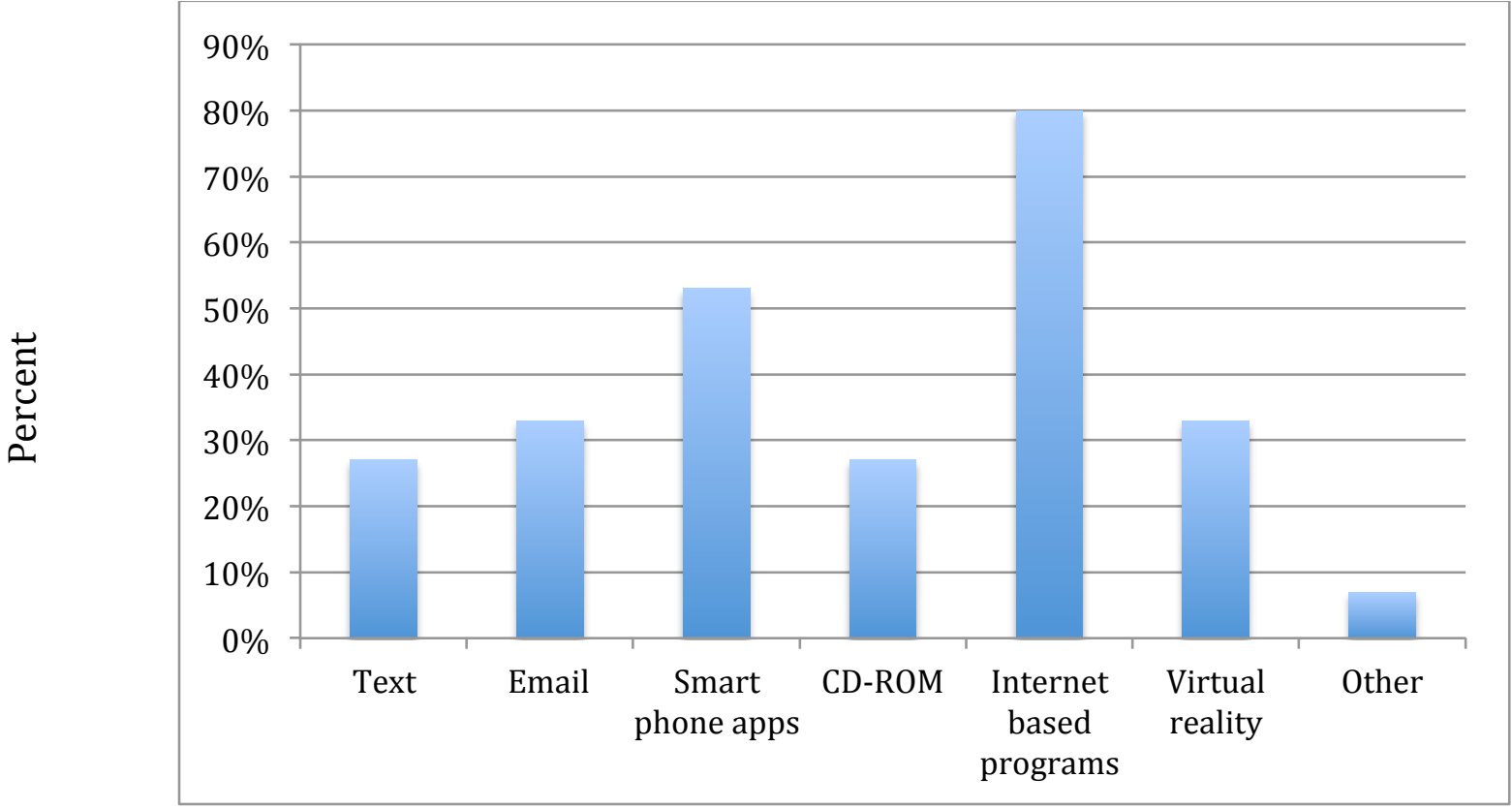

Type of Technology

*Other include Skype and EMR 
When asked about technology based treatments the participant planned to implement into their ED treatment program in the future if not already using, $47 \%$ reported smart phone apps, 37\% reported email, $21 \%$ text and Internet based programs, $16 \%$ CD-ROM or DVD and VR, and $11 \%$ other (i.e., electronic medical records) (Figure 2).

Figure 2. Technologies that health care professionals plan to implement into their

\section{future practices}

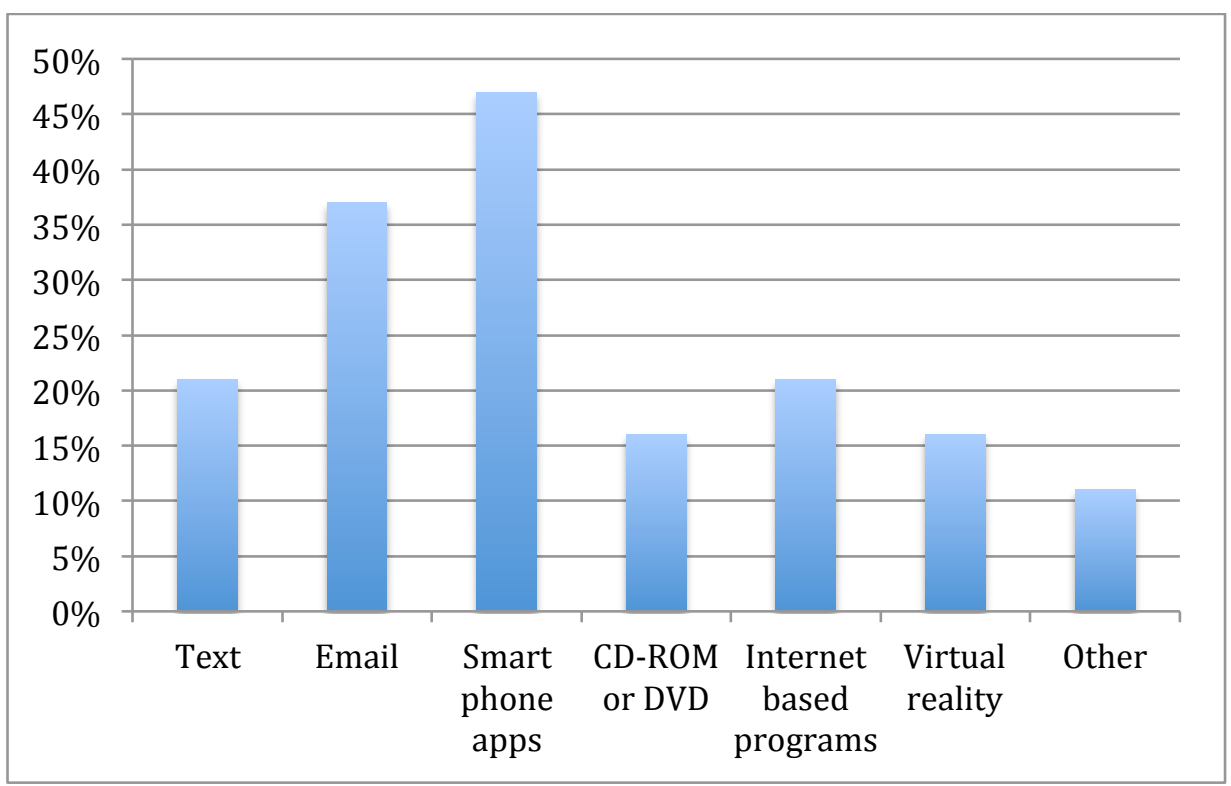

Types of Technology

*Other include Skype and EMR

Spearman rank correlations were conducted for University participants to examine the relationships between the number of technologies used for eating disorder treatment/prevention and student enrollment size, NCAA association participation, 
participant role, practice environment, and geographic location. No significant correlations were found between the number of technologies used and student enrollment size $(r=-0.09, p=0.68)$, region $(r=0.11, p=0.47)$, NCAA association participation $(r=0.28, p=0.06)$, participant role $(r=0.00, p=0.98)$, or environment $(r=-0.21$, $p=0.14)$. A significant correlation was found between practice environment and number of technologies used $(r=0.347, p=0.01)$. It was then determined which practice environments were associated with higher number of technologies used (Table 6).

Table 6. Number of Technologies Used and Practice Environment

\begin{tabular}{|c|c|c|c|c|c|c|c|c|c|c|c|c|}
\hline \multirow[t]{2}{*}{ Setting } & \multicolumn{2}{|r|}{0} & \multicolumn{2}{|r|}{1} & \multicolumn{2}{|r|}{2} & \multicolumn{2}{|c|}{3} & \multicolumn{2}{|r|}{4} & \multicolumn{2}{|c|}{5} \\
\hline & $\mathrm{N}$ & $\%$ & $\mathrm{~N}$ & $\%$ & $\mathrm{~N}$ & $\%$ & $\mathrm{~N}$ & $\%$ & $N$ & $\%$ & $\mathrm{~N}$ & $\%$ \\
\hline University & 7 & 43.75 & 4 & 25.00 & 3 & 18.75 & 1 & 6.25 & 1 & 6.25 & 0 & 0.00 \\
\hline $\begin{array}{l}\text { Private } \\
\text { Practice }\end{array}$ & 3 & 16.67 & 2 & 11.11 & 3 & 16.67 & 7 & 39.89 & 3 & 16.67 & 0 & 0.00 \\
\hline $\begin{array}{l}\text { Treatment } \\
\text { Center }\end{array}$ & 1 & 10.00 & 3 & 30.00 & 4 & 40.00 & 2 & 20.00 & 0 & 0.00 & 0 & 0.00 \\
\hline Other & 1 & 25.00 & 1 & 25.00 & 1 & 25.00 & 0 & 0.00 & 0 & 0.00 & 1 & 25.00 \\
\hline
\end{tabular}


Results showed that participants from University settings were most likely to use $0(43.75 \%)$ or $1(25.00 \%)$ type of technology. Participants from treatment centers were most likely to use 1 (30.00\%) or $2(40.00 \%)$ types of technologies. Participants from private practice were most likely to use 3 (38.89\%) types of technologies.

\section{Focus Group Interviews}

Focus groups lasting between 35-50 minutes were conducted, with 3

participants in each group and 3 total groups, for a total of 9 participants. Groups were heterogeneous in terms of type of environment the healthcare professional practiced (i.e., University setting, private practice setting, and ED facility). Of the total focus group participants, $66 \%$ were from University settings, and 33\% were from private practice facilities. Attitudes reported were based on personal experience of the use of technology within participant's own institution rather than published guidance or the literature. Similar responses were grouped together and reported for each of the talking points presented to participants and are described as follows:

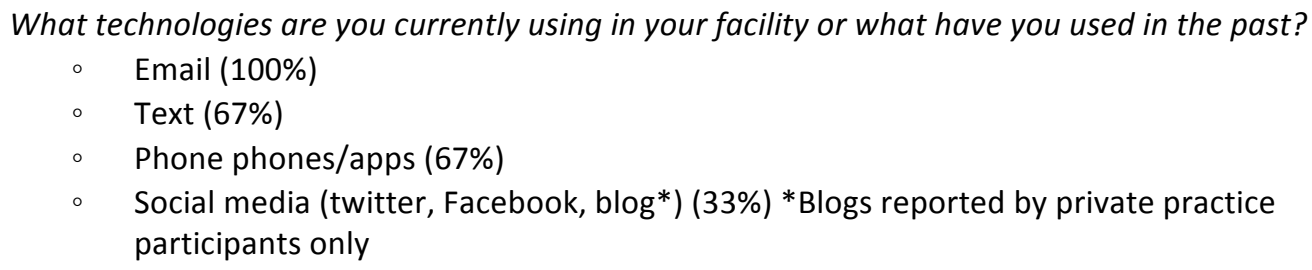

Describe a situation in which technology was a hindrance or an asset to your practice with an ED client.

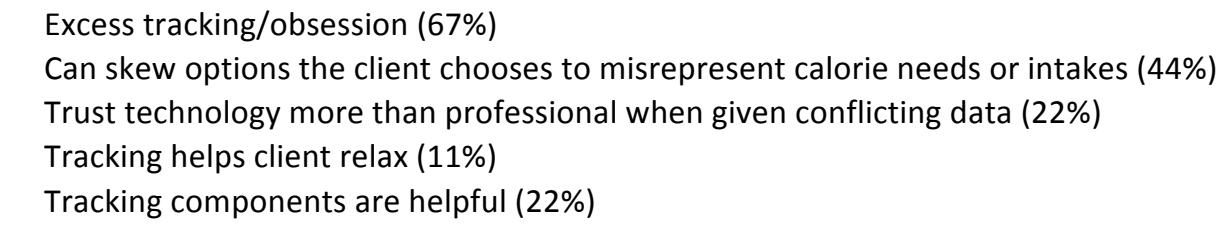

Do you believe that using technology improves eating disorder outcomes? 
- Depends on the client (78\%)

- Helpful for information gathering (11\%)

- $\quad$ Skype can be beneficial (11\%)

- Encourages obsession (11\%)

- Increase awareness and goal setting (22\%)

Can you discuss how your facilities demographics (such as state or region, type of facility, socioeconomic status of the patients, and size of facility) have affected the use of technology?

- Socioeconomic status can affect access to technology (44\%)

- No differences based on demographics (33\%)

- Everyone has something to connect with no matter what his or her demographics (11\%)

- Clients without unlimited texting may have issues with cost of texts (11\%)

- Age (22\%)

- Facility type $(11 \%)$

Discuss your facilities plans to implement technologies into your practice in the future.

- No specific plans (44\%)

- Anonymous Q\&A (11\%)

- Social Media (33\%)

- Unaware of what is available or plan to educate themselves further (44\%)

Describe any concerns you have about the use of technology in eating disorder treatments such as privacy concerns.

- Use extra care so privacy is not breached (56\%)

- Don't share personal information over text or email, only over the phone or in person (56\%)

- Assess client's comfort level with communication over technology on first visit (22\%) 


\section{Chapter 5}

\section{Discussion}

The current study objectives were to examine the types of technologies HCP are integrating into ED treatment and prevention programs, as well as to determine the convenience, usefulness, and effectiveness of these technologies. We also wanted to examine correlations between participants' demographics and the number of technologies used. Plans to implement technologies in the future as well as technologies perceived as helpful, if not already implemented, were also explored.

Throughout both phases of the survey participants were not instructed to decipher between utilizing technology for clerical tasks such as making appointments versus more therapeutic interventions. This study aimed to gather information on technology use as a whole in the ED treatment field. Future studies comparing these two concepts would be an important step in identifying how these technologies are being utilized in the prevention, treatment, and maintenance phases of these programs.

Our results suggest that most HCP working with ED patients are using one or more type of technology in their treatment program. These findings are not surprising due to increased technology use in all healthcare fields. Overall, health care professionals find these technologies useful, effective, and convenient for both their ED patients and health care practitioners. Email, Texting and CD-ROM based programs continuously scored the highest satisfaction scored for all 4 rated factors; however the majority of technologies had mean scores in a fairly close range to one another. It was surprising to researchers that CD-ROM programs were not used more often since they 
scored high satisfaction scores but were rarely reported being used in treatment. Perhaps more in depth research is needed in this area to identify the reasons behind this phenomenon.

Also surprising to researchers was the continuous low satisfaction scores of VR across all four rated factors. The number of respondents was low for those that used VR in their treatment programs $(n=3,7 \%)$ so perhaps a larger study with more diverse opinions on virtual reality would be beneficial. It should also be noted that the majority of the literature on VR in ED treatments was published in the 1990's and little has been studied on the topic since then.

Most HCP reported feeling that one or more additional technologies would be useful to integrate into their practice, and they plan to implement at least one type of technology into their practice in the future. A significant correlation was detected between practice environment and number of technologies used. These finding suggest that among the survey participants, HCP in University environments were most likely to use 0 or 1 technologies in their practice with ED clients. Despite the previously explored potential to incorporate technology based treatments into University ED care programs, our results indicated that these facilities were using the lowest number of technologies. Researchers are unsure of the reasoning for this, but possible causes include budget constraints, lack of knowledge about available technologies, and lack of ability to change treatment programs at will. It is also important to note that due to the low response rate of some of these categories of practice environment (i.e. treatment centers and other), generalization of these findings may not be plausible. From the literature we 
know that technology can provide a way to overcome common barriers to treatment as well as a unique interactive approach to ED treatments. Given that eating disorders are significantly more prevalent on college campuses then in the general population, by not incorporating more technology into ED treatments University HCP's may be missing an opportunity to provide the most diverse and effective treatments possible.

Findings from the focus group interviews with HDP revealed all participants were utilizing technology in their treatment programs, and that they had mixed feelings with using technology to treat ED in their practice. Although all participants reported using technology to some degree, many showed reservations about integrating it into treatment practices. Many participants also indicated a lack of knowledge on the technologies that are available, as well as a lack of time to research and become familiar with these technologies. More discussion between HCP's and better access to information on these technologies might benefit those working with ED patients in the future.

Additional research is needed to determine future technologies that might be beneficial to those working with ED patients. Future studies to look into perceived usefulness and effectiveness of technology use from the patient's perspective may also be helpful in pinpointing the best use of technology in ED treatments. Overall ED is a very complicated disease and treatment approaches need to be tailored to the specific patient. HCP need to follow-up with their patients to verify if the treatment plan is aiding in the treatment process, and may have to adjust it to provide maximum benefits. 
There is no one size fits all treatment to ED, but technology has the potential to be a useful tool in a multidisciplinary treatment approach.

Recruitment was a continuous challenge to researchers throughout this study. Due to low participation rates, researchers were limited both in the statistical analysis available to them as well as generalization of the results. Incentivizing and more varied recruitment methods may encourage higher participation rates in future studies. Targeting conferences with large numbers of sports dietitians, for example, as opposed to utilizing the list servs for these associations may result in more interest and involvement. Additionally, personal phone calls made to each facility had better participation rate then list serv emails, so this may be a beneficial tool in future studies as well, if the resources are available.

Due to the lack of previous research in this area, this study is a starting point for future studies in this area. It is important to continue monitoring the use of technology in the healthcare fields such as ED treatments, as observing the rate of diffusion of technology through a culture provides a lot of information on the future direction of new innovations and treatments.

\section{Limitations}

The response rate for the survey was low so findings may not be generalizable to all HCP working with ED patients. Larger studies may be helpful to achieve more generalized findings. HCP may also have differed from non-completers of the survey, leading to the potential for biased results. For example, health care professionals who completed the questionnaire may have been more apt to use technology because the 
survey was distributed by email, a technology based medium. Additional studies with more varied dissemination approaches may lead to more generalized results.

During the study, researchers did not discern between using technology for clerical tasks such as setting up appointments, versus using it for therapeutic interventions. Future studies separating these two concepts would be beneficial. Implications for future research

Due to the fact that this research was the first of its kind, future studies are needed in this field to identify the most effective ways to incorporate technologies in ED treatment programs. Further investigation is needed to identify how to break down the barriers that are keeping HCP from learning about and utilizing new technologies. Also, it could be beneficial to study the ED patients and their feelings on incorporating technology into ED treatment, as well as the treatment outcomes for those that do have technology based treatment plans. 


\section{REFERENCES}

1. Myers TC, Swan-Kremeier L, Wonderlich S, Lancaster K, Mitchell JE. The use of alternative delivery systems and new technologies in the treatment of patients with eating disorders. Int J Eat Disord. 2004;36(2):123-143.

http://search.ebscohost.com/login.aspx?direct=true \&db=a9h\&AN=13938615\&site=eho st-live. doi: 10.1002/eat.20032.

2. Borreson J. The ECAR study of undergraduate students and information technology, 2007. http://wsip-70-168-75-

185.ri.ri.cox.net/uploaded/websites/ITC/ecar/KeyFindingsStudentUse2007.pdf. Updated 2007. Accessed 10/15, 2012.

3. smith s. The ECAR study of undergraduate students and information technology, 2009. http://wsip-70-168-75-

185.ri.ri.cox.net/uploaded/websites/ITC/ecar/KeyFindingsStudentUse2009.pdf. Updated 2009. Accessed 10/15/2012, 2012.

4. Striegel_moore R, Bulik C. Risk factors for eating disorders. American Psychologist. 2007;62:181-198.

5. Akdevelioglu Y, Gümüs H. Eating disorders and body image perception among university students. Pakistan Journal of Nutrition. 2010;9(12):1187-1191.

http://search.ebscohost.com/login.aspx?direct=true\&db=a9h\&AN=57621511\&site=eho st-live.

6. Hoek HW, van Hoeken D. Review of the prevalence and incidence of eating disorders. Int J Eat Disord. 2003;34(4):383-396. doi: 10.1002/eat.10222.

7. Vohs KD, Heatherton TF. Disordered eating and the transition to college: $A$ prospective study. Int J Eat Disord. 2001;29(3):280-288.

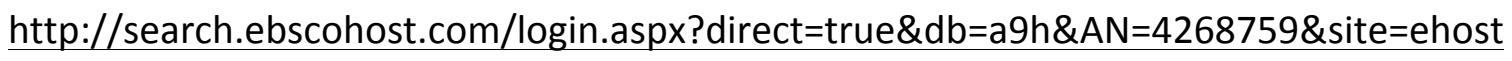
-live.

8. Eisenberg D FAU - Nicklett, Emily,J., FAU NE, Roeder K FAU - Kirz, Nina,E., Kirz NE. Eating disorder symptoms among college students: Prevalence, persistence, correlates, and treatment-seeking. . 0203.

9. ADA reports. position of the american dietetic association: Nutrition intervention in the treatment of anorexia nervosa, bulimia nervosa, and other eating disorders. J Am Diet Assoc. 2006;106(12):2073-2082.

http://search.ebscohost.com/login.aspx?direct=true \&db=c8h\&AN=2009383261\&site=e host-live.

10. Perpiñá C, Botella C, Baños RM. Virtual reality in eating disorders. European Eating Disorders Review. 2003;11(3):261-278.

http://search.ebscohost.com/login.aspx?direct=true \&db=a9h\&AN=10103565\&site=eho st-live.

11. Robinson P, Serfaty M. Computers, e-mail and therapy in eating disorders. European Eating Disorders Review. 2003;11(3):210-221.

http://search.ebscohost.com/login.aspx?direct=true \&db=a9h\&AN=10103561\&site=eho st-live. 
12. Shapiro JR, Bauer S, Andrews E, et al. Mobile therapy: Use of text-messaging in the treatment of bulimia nervosa. Int J Eat Disord. 2010;43(6):513-519.

http://search.ebscohost.com/login.aspx?direct=true \&db=a9h\&AN=53856237\&site=eho st-live.

13. Kraut R, Patterson M, Lundmark V, Kiesler S, Mukophadhyay T, Scherlis W. Internet paradox: A social technology that reduces social involvement and psychological wellbeing? Am Psychol. 1998;53(9):1017-1031.

http://search.ebscohost.com/login.aspx?direct=true\&db=pdh\&AN=amp-53-9-

1017\&site=ehost-live. doi: 10.1037/0003-066X.53.9.1017.

14. Bauer S, Kordy H, Okon E, Meermann R. Technology-enhanced maintenance of treatment gains in eating disorders: Efficacy of an intervention delivered via text messaging. Journal of Consulting \& Clinical Psychology. 2012;80(4):700-706.

http://search.ebscohost.com/login.aspx?direct=true \&db=a9h\&AN=78121982\&site=eho st-live. doi: 10.1037/a002g030.

15. Preziosa A, Grassi A, Gaggioli A, Riva G. Therapeutic applications of the mobile phone. British Journal of Guidance \& Counselling. 2009;37(3):313-325.

http://search.ebscohost.com/login.aspx?direct=true \&db=ehh\&AN=43388330\&site=eho st-live. doi: 10.1080/03069880902957031.

16. Robinson S, Perkins S, Bauer S, Hammond N, Treasure J, Schmidt U. Aftercare intervention through text messaging in the treatment of bulimia nervosa-Feasibility pilot. Int J Eat Disord. 2006;39(8):633-638.

http://search.ebscohost.com/login.aspx?direct=true\&db=a9h\&AN=22930067\&site=eho st-live. doi: 10.1002/eat.20272.

17. Park S, McSweeney JH, Yun GW. Intervention of eating disorder symptomatology using educational communication messages. Communication Research. 2009;36(5):677697. http://search.ebscohost.com/login.aspx?direct=true \&db=psyh\&AN=2009-15231004\&site=ehost-live. doi: 10.1177/0093650209338910.

18. Yager J. E-mail therapy for anorexia nervosa: Prospects and limitations. European Eating Disorders Review. 2003;11(3):198-209.

http://search.ebscohost.com/login.aspx?direct=true \&db=a9h\&AN=10103571\&site=eho st-live.

19. Schmidt U. Getting technical. European Eating Disorders Review. 2003;11(3):147154.

http://search.ebscohost.com/login.aspx?direct=true \&db=a9h\&AN=10103567\&site=eho st-live.

20. Ferrer-García M, Gutiérrez-Maldonado J, Caqueo-Urízar A, Moreno E. The validity of virtual environments for eliciting emotional responses in patients with eating disorders and in controls. Behav Modif. 2009;33(6):830-854.

http://search.ebscohost.com/login.aspx?direct=true \&db=a9h\&AN=45460792\&site=eho st-live. doi: 10.1177/0145445509348056.

21. Huon GF. An initial validation of a self-help program for bulimia. Int J Eat Disord. 1985;4(4):573-588.

http://search.ebscohost.com/login.aspx?direct=true \&db=a9h\&AN=12062233\&site=eho st-live. 
22. Carrard I, Crépin C, Rouget P, Lam T, Golay A, Van dL. Randomised controlled trial of a guided self-help treatment on the internet for binge eating disorder. Behaviour Research \& Therapy. 2011;49(8):482-491.

http://search.ebscohost.com/login.aspx?direct=true \&db=a9h\&AN=61921274\&site=eho st-live. doi: 10.1016/j.brat.2011.05.004.

23. Bardick AD, Berries KB, McCulloch ARM, Witko KD, Spriddle JW, Roest AR. Eating disorder intervention, prevention, and treatment:Recommendations for school counselors. Professional School Counseling. 2004;8(2):168-175.

http://search.ebscohost.com/login.aspx?direct=true \&db=ehh\&AN=15536765\&site=eho st-live.

24. Jacobi C, Abascal L, Taylor CB. Screening for eating disorders and high-risk behavior: Caution. Int J Eat Disord. 2004;36(3):280-295.

http://search.ebscohost.com/login.aspx?direct=true \&db=a9h\&AN=14733699\&site=eho st-live. doi: 10.1002/eat.20048.

25. Gulec H, Moessner M, Mezei A, Kohls E, Túry F, Bauer S. Internet-based maintenance treatment for patients with eating disorders. Professional Psychology: Research \& Practice. 2011;42(6):479-486.

http://search.ebscohost.com/login.aspx?direct=true \&db=a9h\&AN=69651172\&site=eho st-live. doi: $10.1037 / \mathrm{a} 0025806$.

26. Mond JM, Myers TC, Crosby RD, Hay PJ, Mitchell JE. Bulimic eating disorders in primary care: Hidden morbidity still? Journal of Clinical Psychology in Medical Settings. 2010;17(1):56-63.

http://search.ebscohost.com/login.aspx?direct=true \&db=a9h\&AN=48082864\&site=eho st-live. doi: 10.1007/s10880-009-9180-9.

27. Corrigan P. How stigma interferes with mental health care. Am Psychol. 2004;59(7):614-625.

http://search.ebscohost.com/login.aspx?direct=true\&db=pdh\&AN=2004-19091003\&site=ehost-live. doi: 10.1037/0003-066X.59.7.614.

28. Becker AE, Hadley Arrindell A, Perloe A, Fay K, Striegel-Moore R. A qualitative study of perceived social barriers to care for eating disorders: Perspectives from ethnically diverse health care consumers. Int J Eat Disord. 2010;43(7):633-647.

http://search.ebscohost.com/login.aspx?direct=true \&db=a9h\&AN=54336894\&site=eho st-live.

29. Cachelin FM, Rebeck R, Veisel C, Striegel-Moore R. Barriers to treatment for eating disorders among ethnically diverse women. Int J Eat Disord. 2001;30(3):269-278.

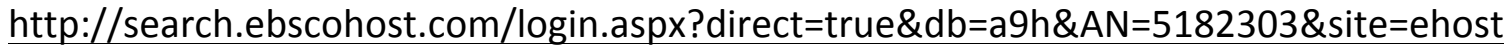
-live.

30. Cachelin FM, Striegel-Moore R. Help seeking and barriers to treatment in a community sample of mexican american and european american women with eating disorders. Int J Eat Disord. 2006;39(2):154-161.

http://search.ebscohost.com/login.aspx?direct=true \&db=a9h\&AN=19443118\&site=eho st-live. doi: 10.1002/eat.20213.

31. Kaye W. Eating disorders: Hope despite mortal risk. American journal psychiatry. 2009;166:1309-1311. 
32. Lynch FL, Dickerson JF, Wilson GT, et al. Cost-effectiveness of guided self-help treatment for recurrent binge eating. Journal of Consulting \& Clinical Psychology. 2010;78(3):322-333.

http://search.ebscohost.com/login.aspx?direct=true \&db=a9h\&AN=51208557\&site=eho st-live. doi: 10.1037/a0018982.

33. Crow SJ, Nyman JA. The cost-effectiveness of anorexia nervosa treatment. Int J Eat Disord. 2004;35(2):155-160.

http://search.ebscohost.com/login.aspx?direct=true \&db=a9h\&AN=12406315\&site=eho st-live. doi: 10.1002/eat.10258.

34. Stewart M, Keel PK, Schiavo RS. Stigmatization of anorexia nervosa. Int J Eat Disord. 2006;39(4):320-325.

http://search.ebscohost.com/login.aspx?direct=true \&db=a9h\&AN=20310728\&site=eho st-live. doi: 10.1002/eat.20262.

35. Crisp A, Gelder M, Rix S. Stigmatization of people with mental illnesses. British Journal of Psychiatry. 2000;177(4).

36. Mojtabai R, Olfson M, Sampson NA, et al. Barriers to mental health treatment:

Results from the national comorbidity survey replication. Psychol Med. 2011;41(8):17511761.

http://search.ebscohost.com/login.aspx?direct=true\&db=a9h\&AN=66813403\&site=eho st-live. doi: 10.1017/S0033291710002291.

37. Personality traits and eating disorders: Mediating effects of self-esteem and perfectionism. International Journal of Clinical Health \& Psychology. 2011;11(2):205-

227.

http://search.ebscohost.com/login.aspx?direct=true \&db=a9h\&AN=60306879\&site=eho st-live.

38. Newton MS, Ciliska D. Internet-based innovations for the prevention of eating disorders: A systematic review*. Eating Disorders. 2006;14(5):365-384.

http://search.ebscohost.com/login.aspx?direct=true \&db=a9h\&AN=23094506\&site=eho st-live. doi: 10.1080/10640260600952522.

39. Calam RM, Slade PD. Sexual experience and eating problems in female undergraduates. Int J Eat Disord. 1989;8(4):391-397.

http://search.ebscohost.com/login.aspx?direct=true \&db=a9h\&AN=12055846\&site=eho st-live.

40. Zabinski MF, Celio AA, Joy Jacobs M, Manwaring J, Wilfley DE. Internet-based

prevention of eating disorders. European Eating Disorders Review. 2003;11(3):183-197.

http://search.ebscohost.com/login.aspx?direct=true\&db=a9h\&AN=10103570\&site=eho st-live.

41. Hebel S. State cuts are pushing public colleges into peril. The Chronicle of Higher Education. 2010. Available from:

http://publicaffairsunlv.dyndns.org/articles/Daily\%20Clips/03-14-

2010.State\%20Cuts\%20Are\%20Pushing\%20Public\%20Colleges\%20Into\%20Peril\%20(The \%20Chronicle\%20of\%20Higher\%20Education).pdf. 
42. Hurtado S, Milem J, Clayton-Pederson A, Allen W. Enhancing campus climates for racial/ethnic diversity: Educational policy and practice. The Review of Higher Education. 1998;21(3):279.

43. Mann T, Nolen-Hoeksema S, Huang K, Burgard D, Wright A, Hanson K. Are two interventions worse than none? joint primary and secondary prevention of eating disorders in college females. Health Psychology. 1997;16(3):215-225. doi: 10.1037/02786133.16.3.215.

44. Falissard B. Eating disorders: Interactions between human nutrition research and food behaviours. Trends Food Sci Technol. 2007;18(5):281-284.

http://search.ebscohost.com/login.aspx?direct=true\&db=a9h\&AN=24863725\&site=eho st-live. doi: 10.1016/j.tifs.2007.01.003.

45. Melville KM, Casey LM, Kavanagh DJ. Dropout from internet-based treatment for psychological disorders. British Journal of Clinical Psychology. 2010;49(4):455-471.

http://search.ebscohost.com/login.aspx?direct=true \&db=a9h\&AN=60283885\&site=eho st-live. doi: 10.1348/014466509X472138.

46. Krueger, R.A. Focus groups. A practical guide for applied research ( $4^{\text {th }}$ ed.) Los Angeles, Ca: Sage. 2009; pg 205

47. Rogers, Evertt M. 2003, Diffusion of Innovations, $5^{\text {th }}$ ed. Free Press, New York, p221. 48. McDonald, J.H. 2009. Handbook of Biological Statistics (2nd ed.). Sparky House Publishing, Baltimore, Maryland.

49. Program: Electronic Library \& Information Systems. 2013, Vol. 47 Issue 4, p424-436. $13 p$. 


\section{APPENDICES}

\section{Appendix A: IRB Approval}

WVU IRB Approved Protocol H-24544 Title: Technology and Prevention and Treatment of Eating Disorders on April 1, 2013

The 36 page document including consent can be found in the BRAAN 2 system with the tracking number 24544. 


\section{Appendix B: Email sent to potential participant}

As a graduate student in the Dietetic Internship program at West Virginia University, I am seeking your input on the various technologies being used by facilities in their Eating Disorder treatments as part of the requirements for my Masters of Science degree. Examples of the technologies being looked at are email, text messaging, and virtual reality. I am looking for health care professionals that work with an eating disorder program to briefly describe what technologies are being used and how helpful they feel these technologies are. If you meet the qualifications and would like to participate in our study, please follow the link below to a brief 5 minute survey. If you know of anyone else who would qualify for the survey, please feel free to send the link to them. Your responses are greatly appreciated. I thank you in advance for your time.

The survey link is: http://wvu.qualtrics.com/SE/?SID=SV_87WSz3P3h0k48Bf

Thanks again for your time!

Contact Info: Jessie Popelka (email: jtpopelka@mix.wvu.edu) 


\section{Appendix C: Survey sent to participants}

Which of the following best describes the primary environment in which you are practicing

University or College setting

Private Practice

Treatment Center

Other

What state are you located?

What is the current student enrollment of your University if associated with one?

Less than 5,000

$5,000-10,000$

$10,000-20,000$

$20,000-30,000$

$30,000-40,000$

40,000 or more

No association

What is your role in your institutions' eating disorder intervention?

Registered Dietitian

Nurse

Counselor

Nurse Practitioner

Medical Doctor

Physicians Assistant

Researcher

Other

Which of the following best describes the location of your institution?

Urban

Suburban

Rural

If you are associated with a University, is the athletics program associated with the NCAA program?

Yes

No

Not associated with a University or College

If associated with a University, Does your University offer student health insurance?

Yes

No

Not associated with a University or College

If associated with a University, Does your University offer student health insurance?

Yes

No

Not associated with a University or College

Does your institution use text messaging as part of your eating disorder intervention and treatments?

Yes

No

Not sure

Does your institution use Email as part of your eating disorder intervention and treatments?

Yes

No 
Not Sure

Does your institution use smart phone apps as part of your eating disorder intervention and treatments?

Yes

No

Not Sure

Does your institution use Virtual Reality as part of your eating disorder intervention and treatments?

Yes

No

Not Sure

Does your institution use CD-ROM or DVD programs as part of your eating disorder intervention and treatments? Yes

No

Not Sure

Does your institution use Internet based programs as part of your eating disorder intervention and treatments? Yes

No

Not Sure

Does your institution use any other technology-based programs as part of your eating disorder intervention and treatments?

Yes

No

Not Sure

Please list any other technology-based programs used by your institution in eating disorder interventions and treatments:

if applicable, how would you rate your experience with using Email in your eating disorder intervention in terms of the following:

\begin{tabular}{|c|c|c|c|c|c|}
\hline & $\begin{array}{c}\text { Very } \\
\text { dissatisfied }\end{array}$ & $\begin{array}{l}\text { Somewhat } \\
\text { dissatisfied }\end{array}$ & Neutral & $\begin{array}{c}\text { Somewhat } \\
\text { satisfied }\end{array}$ & $\begin{array}{c}\text { Very } \\
\text { satisfied }\end{array}$ \\
\hline $\begin{array}{l}\text { Usefulness } \\
\text { Effectiveness } \\
\text { Convenience for health care } \\
\text { practitioner } \\
\text { Convenience for ED patient }\end{array}$ & & & & & \\
\hline
\end{tabular}

If applicable, how would you rate your experience with using text messaging in your eating disorder intervention in terms of the following:

\begin{tabular}{|c|c|c|c|c|c|}
\hline & $\begin{array}{c}\text { Very } \\
\text { dissatisfied }\end{array}$ & $\begin{array}{l}\text { Somewhat } \\
\text { dissatisfied }\end{array}$ & Neutral & $\begin{array}{l}\text { Somewha } \\
\text { t satisfied }\end{array}$ & $\begin{array}{c}\text { Very } \\
\text { satisfied }\end{array}$ \\
\hline $\begin{array}{l}\text { Usefulness } \\
\text { Effectiveness } \\
\text { Convenience for health care } \\
\text { practitioner } \\
\text { Convenience for ED patient }\end{array}$ & & & & & \\
\hline
\end{tabular}


If applicable, how would you rate your experience with using Smart phone apps in your eating disorder intervention in terms of the following:

\begin{tabular}{|c|c|c|c|c|c|}
\hline & $\begin{array}{c}\text { Very } \\
\text { dissatisfied }\end{array}$ & $\begin{array}{l}\text { Somewhat } \\
\text { dissatisfied }\end{array}$ & Neutral & $\begin{array}{c}\text { Somewhat } \\
\text { satisfied }\end{array}$ & $\begin{array}{l}\text { Very } \\
\text { satisfied }\end{array}$ \\
\hline $\begin{array}{l}\text { Usefulness } \\
\text { Effectiveness } \\
\text { Convenience for health care } \\
\text { practitioner } \\
\text { Convenience for ED patient }\end{array}$ & & & & & \\
\hline
\end{tabular}

If applicable, how would you rate your experience with using Virtual reality in your eating disorder intervention in terms of the following:

\begin{tabular}{|c|c|c|c|c|c|}
\hline & $\begin{array}{c}\text { Very } \\
\text { dissatisfied }\end{array}$ & $\begin{array}{l}\text { Somewhat } \\
\text { dissatisfied }\end{array}$ & Neutral & $\begin{array}{c}\text { Somewhat } \\
\text { satisfied }\end{array}$ & $\begin{array}{c}\text { Very } \\
\text { satisfied }\end{array}$ \\
\hline $\begin{array}{l}\text { Usefulness } \\
\text { Effectiveness } \\
\text { Convenience for health care } \\
\text { practitioner } \\
\text { Convenience for ED patient }\end{array}$ & & & & & \\
\hline
\end{tabular}

If applicable, how would you rate your experience with using CD-Roms or DVD programs in your eating disorder intervention in terms of the following:

\begin{tabular}{l|llll} 
& Very & Somewhat & Somewhat & $\begin{array}{c}\text { Very } \\
\text { satisfied }\end{array}$ \\
\hline Usefulness & & & \\
Effectiveness & & & \\
Convenience for health care & & & \\
practitioner & & & \\
Convenience for ED patient & &
\end{tabular}

If applicable, how would you rate your experience with using Internet based programs in your eating disorder intervention in terms of the following:

\begin{tabular}{|c|c|c|c|c|c|}
\hline & $\begin{array}{c}\text { Very } \\
\text { dissatisfied }\end{array}$ & $\begin{array}{l}\text { Somewhat } \\
\text { dissatisfied }\end{array}$ & Neutral & $\begin{array}{c}\text { Somewhat } \\
\text { satisfied }\end{array}$ & $\begin{array}{c}\text { Very } \\
\text { satisfied }\end{array}$ \\
\hline $\begin{array}{l}\text { Usefulness } \\
\text { Effectiveness } \\
\text { Convenience for health care } \\
\text { practitioner } \\
\text { Convenience for ED patient }\end{array}$ & & & & & \\
\hline
\end{tabular}

If applicable, how would you rate your experience with using other technology based treatments in your eating disorder intervention in terms of the following:

\begin{tabular}{|c|c|c|c|c|c|}
\hline & $\begin{array}{c}\text { Very } \\
\text { dissatisfied }\end{array}$ & $\begin{array}{l}\text { Somewhat } \\
\text { dissatisfied }\end{array}$ & Neutral & $\begin{array}{l}\text { Somewha } \\
\text { t satisfied }\end{array}$ & $\begin{array}{c}\text { Very } \\
\text { satisfied }\end{array}$ \\
\hline \multicolumn{6}{|l|}{ Usefulness } \\
\hline \multicolumn{6}{|l|}{ Effectiveness } \\
\hline \multirow{2}{*}{\multicolumn{6}{|c|}{$\begin{array}{l}\text { Convenience for health care } \\
\text { practitioner }\end{array}$}} \\
\hline & & & & & \\
\hline Convenience for ED patient & & & & & \\
\hline
\end{tabular}


Please check all of the following technology based treatments that your institution plans on implementing into its eating disorder treatment program in the future if not used currently:

Text

Email

Smart phone apps

CD-ROM or DVD

Internet based programs

Virtual reality

Other

Please check all of the following technology based treatments that you feel would be useful to integrate into your institutions eating disorder treatment program in the future if not used currently:

Text

Email

Smart phone apps

CD-ROM

Internet based programs

Virtual reality

Other

Thank you for your time. If you have any questions or concerns please contact jtpopelka@mix.wvu.edu. If anyone you know would qualify for the survey and be interested in taking part in the study, please forward on the link. Thank you. 
Appendix D: Focus Group Questions And Prompts

- Can you describe a specific time when a technology was an asset to your practice with an ED client?

- Can you describe a specific time when using a technology was a hindrance to your practice with an ED client?

- Discuss how your specific facilities demographics effects the use of technology with ED patients

- Discuss your facilities plans to implement technologies into your practice in the future

- Describe any concerns you have about the use of technology in ED treatments 